University of Nebraska - Lincoln

DigitalCommons@University of Nebraska - Lincoln

Transactions of the Nebraska Academy of Sciences and Affiliated Societies

Nebraska Academy of Sciences

$3-31-2021$

\title{
Small mammals killed in discarded bottles along roadsides in central Nebraska
}

Owen J. Johnson

NGPC, owen.johnson0752@gmail.com

Keith Geluso

University of Nebraska at Kearney, gelusok1@unk.edu

Follow this and additional works at: https://digitalcommons.unl.edu/tnas

Part of the Biodiversity Commons, and the Ecology and Evolutionary Biology Commons

Johnson, Owen J. and Geluso, Keith, "Small mammals killed in discarded bottles along roadsides in central Nebraska" (2021). Transactions of the Nebraska Academy of Sciences and Affiliated Societies. 531.

https://digitalcommons.unl.edu/tnas/531

This Article is brought to you for free and open access by the Nebraska Academy of Sciences at DigitalCommons@University of Nebraska - Lincoln. It has been accepted for inclusion in Transactions of the Nebraska Academy of Sciences and Affiliated Societies by an authorized administrator of DigitalCommons@University of Nebraska - Lincoln. 


\title{
Small mammals killed in discarded bottles along roadsides in central Nebraska
}

\author{
Owen J. Johnson and Keith Geluso \\ Department of Biology, University of Nebraska at Kearney, Kearney, Nebraska, 68849 USA \\ Corresponding author: Keith Geluso; 308-865-8982; email gelusok1@unk.edu
}

\begin{abstract}
Littered debris along roadways traps and kills small vertebrates. In Nebraska, at least 20 species of small mammals are small enough to enter openings of discarded bottles and cans. We surveyed roadsides for littered bottles and cans containing vertebrate remains in central parts of the state. We observed 459 bottles and 278 aluminum cans along $17.6 \mathrm{~km}$ of roadsides in Nebraska. Littered bottles contained 41 vertebrate remains representing nine taxa of small mammals. Glass bottles contained the majority of individuals, plastic bottles had a few individuals, and no vertebrate remains were detected in aluminum cans. Harvest mice (Reithrodontomys spp.) were the most frequently observed taxa trapped in bottles, followed by short-tailed shrews (Blarina spp.). Remains of a juvenile Hispid Cotton Rat (Sigmodon hispidus) in a glass bottle suggest that more species are at risk when individuals are young. Bottles with openings higher than their base contained more vertebrates (21.1\%) than those lying flat (3.8\%) or those with openings facing downward (1.2\%). Overall, about $5.7 \%$ of bottles had vertebrate remains in Nebraska, which is slightly greater than studies in the eastern United States. Densities of littered bottles were much lower along roads in Nebraska than roadways in the eastern United States, resulting in fewer mortalities per $\mathrm{km}$. Human population density appears associated with littered debris, thus numbers of vertebrates killed in these roadside hazards likely is greater in eastern Nebraska and near population centers where most of the state's population reside. In Nebraska, six species of small mammals are species of conservation need, and thus, at risk from littered debris. Reduction and removal of litter along roadsides not only is aesthetically pleasing, but it can also reduce mortality of small mammals and other animals, such as small insects.
\end{abstract}

Keywords: Aluminum cans, bottles, debris, glass bottles, litter, littering, Nebraska, roads, roadside ditches, rodents, shrews, small mammals

DOI: $10.32873 /$ unl.dc.tnas.41.4

\section{Introduction}

It is easy to understand how human activities, such as construction of roads, conversion of prairies for agricultural development, and expansion of urban areas, negatively affect animals and their habitats (e.g., Samson and Knopf 1994, Forman and Alexander 1998, Gibbs and Shriver 2002, Keller and Largiadèr 2003, Glista et al. 2009, Perkl et al. 2018, Taylor-Brown et al. 2019). Other actions by humans, however, have less visible impacts on animals and their habitats (Krutilla 1967, Rochman et al. 2016). Littered debris, a common form of pollution, occurs when human-made objects are discarded improperly, with some of these items persisting in environments for long periods (Brannon et al. 2010). Littered debris is known to negatively affect various groups of vertebrates, including birds (Gall and Thompson 2015), fishes (Gall and Thompson 2015), reptiles (Dreier et al. 2015a, Gall and Thompson 2015), amphibians (Benedict and Billeter 2004), and mammals (Pagels and French 1987, Benedict and Billeter 2004). Although litter comes in many forms, discarded bottles are a common type that accumulate in roadside right-of-ways in the United States and other countries (e.g., Debernardi et al. 1997, Benedict and Billeter 2004, Kolenda et al. 2018).

Discarded glass and plastic bottles have been known to kill small vertebrates for decades (Morris and Harper 1965, Clegg 1966). Littered bottles effectively act as pitfall traps. Small mammals likely enter bottles to search for food, water, and burrows, as well as to explore (Morris and Harper 1965, Gerard and Feldhamer 1990). Once inside, individuals are unable to escape due to slick inside surfaces and increasing slope of the narrowing neck (Morris and Harper 1965). The most fatal position for small 
mammals occurs when bottles lie on a hill, with openings higher than the bottoms (Benedict and Billeter 2004, Hamed and Laughlin 2015). However, bottles also can be fatal when lying flat (Morris and Harper 1965, Benedict and Billeter 2004). Discarded bottles are such effective traps for some species and are sufficiently abundant in some areas, that searching for discarded bottles has been used to delineate distributions of shrews and other small mammals (Morris and Harper 1965, Pagels and French 1987, Dreier et al. 2015b).

In Nebraska, about 20 species of small mammals can be trapped in littered bottles on the basis of their small size $(<60 \mathrm{~g})$, including 6 species of shrews and 14 rodents (Jones 1964, Genoways et al. 2008). No prior study has examined the extent of mortality for vertebrate species entrapped in littered bottles in the Great Plains. The objectives of this study were to examine the prevalence of debris with vertebrate remains along roadsides, determine which species are most susceptible to being trapped within littered bottles and cans, and identify characteristics of debris most fatal to small vertebrates in central Nebraska.

\section{Methods}

From May to July 2009, we searched for and counted discarded bottles and aluminum cans along roadside right-of-ways in nine counties (Buffalo, Cherry, Custer, Dawson, Furnas, Hall, Harlan, Kearney, and Lincoln) throughout central Nebraska. We only searched each area once during the study. We visually detected most bottles and cans but also detected bottles with our feet in areas with dense grass or leaf cover (Benedict and Billeter 2004). We mainly focused efforts in roadsides associated with upland grasslands because low-lying areas generally contained tall vegetation during this summer period, preventing us from locating littered debris. We recorded the position of bottles and cans that contained vertebrates as flat $\left(0\right.$ to $\left.<10^{\circ}\right)$, kill $\left(>10^{\circ}\right.$ and opening upward), or down $\left(>10^{\circ}\right.$ and opening downward), as well as size (12 oz, $32 \mathrm{oz}$, or other), material (glass or plastic), color (clear, white, or brown), slope of roadside (steep, moderate, none), and dominant vegetation (grass, shrub, or wooded). We recorded the number of bottles with attached lids, although these bottles were not included herein unless specifically stated. For bottles, we did not identify material (i.e., glass or plastic) for those that did not contain vertebrates. Crania and mandibles of small mammals were identified to the lowest taxon possible using various taxonomic keys (Carraway 1995, Genoways et al. 2008). Representative voucher materials were deposited in the natural history collection at the Sternberg Museum of Natural History, Fort Hays State University, Hays, Kansas, USA. Following Benedict and Billeter (2004), we broke glass bottles to prevent further mortalities along roadways.

\section{Results}

We observed a total of 459 bottles without lids from searching $17.6 \mathrm{~km}$ of roadside right-of-ways, with an average of 26 bottles/ $\mathrm{km}$ (Tables 1 and 2). We detected an additional 90 bottles with lids for an overall total of 31.2 bottles $/ \mathrm{km}$. Of total bottles without lids, $69 \%$ were roughly flat, $18.6 \%$ were lying at an angle with the opening facing downward, and $12.4 \%$ had bottle openings facing upward in the kill position (Table 1). We observed 278 aluminum cans, with $75.9 \%$ lying flat, $13.7 \%$ facing downward, and $10.4 \%$ facing upward (Table 1).

No aluminum cans contained vertebrate remains. A total of $5.7 \%(n=26)$ of bottles had vertebrate remains, representing 41 individuals of nine taxa of small mammals (Table 2 ), which equates to 2.3 vertebrate mortalities per $\mathrm{km}$ of roadway. Of those with remains, 24 were glass bottles whereas two were plastic bottles (Table 2). Bottles with openings higher than their base contained more vertebrates $(21.1 \%)$ than those flat $(3.8 \%)$ or facing downward (1.2\%). Bottles with vertebrate remains were observed in all three roadside habitats (woods, shrubs, and grass), as well as roadsides that were flat, moderately steep, and steep. The most vertebrates documented in a single bottle was four, three Elliot's Short-tailed Shrews (Blarina hylophaga) and one mouse (Peromyscus spp.), on a wooded slope in Harlan County. Although not quantified, a number of bottles also contained insects and other invertebrates (flies, beetles, isopods, spiders, snails, and crickets), with some containing tens to hundreds of beetles, including many carrion beetles (Nicrophorus spp.), although none were identified as endangered American Burying Beetles (Nicrophorus americanus).

Although not the original purpose of this research, we documented two county records based on remains discovered in littered bottles. We discovered a Least Shrew (Cryptotis parva) from Dawson County (Nebraska Hwy 47, Hiles Canyon, $7.3 \mathrm{~km} \mathrm{~S}$ Interstate $80,40^{\circ} 50.829^{\prime} \mathrm{N}$, $100^{\circ} 09.966^{\prime} \mathrm{W}$ ) and a Northern Short-tailed Shrew (Blarina brevicauda) from Kearney County (County Road W, $1.5 \mathrm{~km}$ W Hwy 44, 40³9.265'N, 9906.238'W). 
Table 1. Number, position, color, material, and size of littered bottles observed along roadways in Nebraska with vertebrate remains. Bottle positions include flat (bottles with $<10^{\circ}$ slope), kill (bottles with opening facing upward and on $>10^{\circ}$ slope), down (bottles with opening facing downhill at $>10^{\circ}$ slope). $n=25$ for littered debris (bottles) with vertebrates. We failed to note characteristics of one bottle in notes, so total bottles equals 458 .

\begin{tabular}{|c|c|c|c|c|}
\hline Characteristics & \# bottles & $\%$ bottles & \# cans & $\%$ cans \\
\hline Flat & 316 & $69.0 \%$ & 211 & $75.9 \%$ \\
\hline Kill (up) & 57 & $12.4 \%$ & 29 & $10.4 \%$ \\
\hline Down & 85 & $18.6 \%$ & 38 & $13.7 \%$ \\
\hline TOTALS & 458 & & 278 & \\
\hline Debris w/vertebrates & \# items & $\%$ items & & \\
\hline Flat & 12 & 48 & 0 & 0 \\
\hline Kill & 12 & 48 & 0 & 0 \\
\hline Down & 1 & 4 & 0 & 0 \\
\hline \multicolumn{5}{|l|}{ Color } \\
\hline Brown & 15 & 60 & & \\
\hline Clear & 9 & 36 & & \\
\hline White ${ }^{a}$ & 1 & 4 & & \\
\hline \multicolumn{5}{|l|}{ Material } \\
\hline Glass & 23 & 92 & & \\
\hline Plastic $^{a}$ & 2 & 8 & & \\
\hline Aluminum cans & 0 & 0 & & \\
\hline \multicolumn{5}{|l|}{ Size } \\
\hline $12 \mathrm{oz}(360 \mathrm{ml})$ & 20 & $87 \%$ & & \\
\hline $32 \mathrm{oz}(960 \mathrm{ml})$ & 1 & $4.3 \%$ & & \\
\hline othera & 2 & $8.7 \%$ & & \\
\hline not recorded & 2 & $N / A$ & & \\
\hline
\end{tabular}

${ }^{\mathrm{a}}$ Included one $750 \mathrm{ml}$ bottle and one plastic white radiator overflow bottle/container $\sim 10 \mathrm{~cm}$ by $15 \mathrm{~cm}$.

Table 2. A survey of littered bottles and cans along roadsides in various counties in Nebraska, including numbers of vertebrate remains in them. Numbers for bottles do not include those with lids. Numbers of cans were not recorded in three counties.

\begin{tabular}{|c|c|c|c|c|c|c|c|c|c|c|}
\hline & Buffalo & Cherry & Custer & Dawson & Furnas & Hall & Harlan & Kearney & Lincoln & TOTALS \\
\hline $\mathrm{km}$ surveyed & 0.9 & 2.32 & 1.24 & 3.1 & 2.9 & 0 & 2.62 & 2.3 & 2.22 & 17.6 \\
\hline Total bottles & 23 & 107 & 5 & 24 & 11 & 1 & 84 & 127 & 77 & 459 \\
\hline Total aluminum cans & 39 & -- & 9 & 91 & 29 & -- & 36 & -- & 74 & 278 \\
\hline Bottles with vertebrates & 3 & 1 & 0 & 2 & 1 & 1 & 5 & 8 & 5 & 26 \\
\hline Hours walked & 2 & 4 & 1.5 & 6 & 2 & -- & 4.33 & 7 & 5.17 & 32 \\
\hline \multicolumn{11}{|l|}{ Species of vertebrates } \\
\hline Blarina brevicauda & 0 & 1 & 0 & 1 & 0 & 0 & 0 & 1 & 0 & $3(7.3 \%)$ \\
\hline Blarina hylophaga & 0 & 0 & 0 & 0 & 0 & 0 & 4 & 0 & 2 & $6(14.6 \%)$ \\
\hline Cryptotis parva & 0 & 0 & 0 & 1 & 0 & 0 & 0 & 0 & 1 & $2(4.9 \%)$ \\
\hline Microtus ochrogaster & 0 & 0 & 0 & 0 & 1 & 0 & 0 & 0 & 0 & $1(2.4 \%)$ \\
\hline Microtus pennsylvanicus & $s 0$ & 0 & 0 & 0 & 0 & 1 & 0 & 2 & 0 & $3(7.3 \%)$ \\
\hline Peromyscus leucopus & 0 & 0 & 0 & 0 & 0 & 0 & 1 & 0 & 0 & $1(2.4 \%)$ \\
\hline Peromyscus spp. & 0 & 0 & 0 & 0 & 0 & 0 & 2 & 1 & 2 & $5(12.2 \%)$ \\
\hline Reithrodontomys spp. & 3 & 0 & 0 & 0 & 0 & 1 & 2 & 6 & 3 & $15(36.6 \%)$ \\
\hline Sigmodon hispidus & 0 & 0 & 0 & 0 & 1 & 0 & 0 & 0 & 0 & $1(2.4 \%)$ \\
\hline Sorex cinereus & 0 & 0 & 0 & 0 & 0 & 1 & 0 & 3 & 0 & $4(9.8 \%)$ \\
\hline TOTALS & 3 & 1 & 0 & 2 & 2 & 3 & 9 & 13 & 8 & 41 \\
\hline
\end{tabular}




\section{Discussion}

Four species of shrews occur in central Nebraska (Family Soricidae; Jones 1964, Genoways et al. 2008), and we documented each of these species in roadside litter. Three of the four species previously were documented in littered bottles in the eastern United States (Benedict and Billeter 2004, Brannon et al. 2010). Documentation of Elliot's Short-tailed Shrew represents the first observation for this species in such a trap (Thompson et al. 2011). Although only $36.6 \%$ of fatalities were shrews in our survey, studies in eastern parts of the United States demonstrate that shrews compose a majority of fatalities in littered bottles (Pagels and French 1987, Gerard and Feldhamer 1990, Benedict and Billeter 2004, Brannon et al. 2010, Brannon and Bargelt 2013, Hamed and Laughlin 2015). For example, three shrew species composed $76.7 \%$ of fatalities in Virginia (Benedict and Billeter 2004), three species composed 83.2\% in Tennessee (Hamed and Laughlin 2015), and four species composed $90 \%$ in North Carolina and Georgia (Brannon and Bargelt 2013). We primarily focused searches in open upland habitats to facilitate locating bottles during warm-season months, which is not an ideal season to search because vegetation obscures littered debris (Pagels and French 1987, Gerard and Feldhamer 1990). We suspect that shrews would constitute a greater percentage of mortalities if our surveys included roadways in low-lying areas with dense, moist environments, where shrews tend to have higher abundances and species richness (Matlack et al. 2002, Berman et al. 2007, Thompson et al. 2011).

In addition to shrews, littered bottles in central Nebraska also fatally trapped at least five species of rodents, consisting of $63.4 \%$ of vertebrate mortalities. Most of the species that we observed fatally trapped in littered bottles previously have been reported in this type of debris (Pagels and French 1987, Gerard and Feldhamer 1990, Benedict and Billeter 2004, Dreier et al. 2015b). The Hispid Cotton Rat (Sigmodon hispidus) represents the first observation for this rodent in littered bottles. This individual represented a juvenile based on mandible length and tooth wear and eruption. Moreover, this observation demonstrates that young individuals also are at risk for species that are too large as adults to enter bottle openings, increasing the number of species likely to succumb to littered debris. We also suspect additional species are included in our sample, as skulls of Peromyscus and Reithrodontomys generally were not intact and were difficult to identify to species, with two species of each genera occurring in the study area (Jones 1964).
Studies in the eastern United States report a relatively low frequency of rodents in littered bottles (Pagels and French 1987, Gerard and Feldhamer 1990, Benedict and Billeter 2004, Brannon et al. 2010, Brannon and Bargelt 2013, Hamed and Laughlin 2015). Our surveys in dry, upland habitats likely reflects the greater prevalence of rodents in this survey. Documentation of five species is similar to studies in the eastern United States (Pagels and French 1987, Gerard and Feldhamer 1990, Benedict and Billeter 2004, Brannon et al. 2010, Brannon and Bargelt 2013, Hamed and Laughlin 2015). However, rodent diversity is lowest in the eastern United States compared to farther west (Hafner et al. 1998). Thus, with additional field efforts in other regions of Nebraska and in other regions in the central and western United States, more species of rodents (and shrews) will be discovered in littered bottles. In Nebraska, this might include two shrews (Dwarf Shrew [Sorex nanus] and Merriam's Shrew [Sorex merriami]) and three rodents (Olive-backed Pocket Mouse [Perognathus fasciatus], Silky Pocket Mouse [Perognathus flavus], and eastern subspecies of the Plains Pocket Mouse [Perognathus flavescens perniger]) listed as species of greatest conservation need in the state (Schneider et al. 2018).

Other studies have documented animals other than small mammals in littered bottles, such as lizards, salamanders, and snakes as well as invertebrates (Morris and Harper 1965, Gerard and Feldhamer 1990, Castilla and Bauwens 1991, Benedict and Billeter 2004, Brannon et al. 2010, Brannon and Bargelt 2013). Although we did not detect other vertebrate taxa in littered bottles during our study, Dreier et al. (2015a) discovered a Prairie Lizard (Sceloporus consobrinus) in south-central Nebraska in Dawson County. We also documented that many insects, especially carrion beetles, appear common in bottles (Morris and Harper 1965, Gerard and Feldhamer 1990). Studies are lacking in the literature on the diversity and frequency of invertebrates trapped in littered debris, which likely is important in areas where sensitive or threatened species reside. The effects that discarded bottles have on populations of small vertebrates and insects has yet to be quantified. We suspect it can be substantial for slow reproducing, or rare, threatened, and sensitive species, including invertebrates, depending on densities of humans and littered debris.

Prevalence of bottles with vertebrates (5.7\%) in central Nebraska was slightly higher compared to studies in the eastern United States. However, densities of bottles along roadways were much lower in Nebraska (26 bottle per $\mathrm{km}$ ) yielding fewer overall mortalities (2.3 individuals) 
per $\mathrm{km}$ of roadway. In Virginia, about $4 \%$ of bottles contained vertebrates with a reported average of 2,461 bottles per km (Benedict and Billeter 2004). That study yielded 183 vertebrates killed per $\mathrm{km}$ of roadway, but unlike our study, roadways were moderately to heavily traveled, such as interstates in a heavily populated area. Another study in Virginia observed 71 mammal mortalities and 577 bottles per km of roadway (Pagels and French 1987). In the tri-state area of North Carolina, South Carolina, and Georgia, $4.5-4.7 \%$ of bottles contained vertebrates, with 239 bottles per $\mathrm{km}$, yielding 25 animals per $\mathrm{km}$ of roadway (Brannon et al. 2010, Brannon and Bargelt 2013). In Tennessee, $3.6 \%$ of debris items contained vertebrate remains, with about 26 mortalities per $\mathrm{km}$ of roadway (Hamed and Laughlin 2015). It is unclear whether our slightly higher prevalence $(5.7 \%$ of bottles with vertebrates) is biologically meaningful from those surveys in the eastern United States. One study mentions that individuals might seek available drinking water from littered debris, especially in dry conditions (Gerard and Feldhamer 1990). If so, drier habitats, such as our study area, might cause small mammals to enter containers at greater frequencies to obtain water. Overall, rates of mortality, therefore, likely reflect the interplay of vertebrate density, litter abundance, and likelihood of species to enter debris.

Human population density and the resulting greater number of vehicles on roadways appears to reflect differences in bottle density and vertebrates killed along roadsides in the United States. In studies along highways in Virginia (Pagels and French 1987, Benedict and Billeter 2004), population density of humans was 179 people per square mile, but in Nebraska the population density only was 22.3 people per square mile in 2000 (U.S. Census Bureau; www.census.gov/data.html). In fact, to facilitate finding bottles in some sparsely populated counties in Nebraska, we collected data from near campgrounds, recreation areas, or just outside of towns, but numbers of bottles still were much lower than other studies in the eastern United States. We predict that numbers of vertebrates killed in these roadside hazards likely is greater in eastern parts of Nebraska and near population centers, where most of the state's population reside. Additional factors affecting quantity of littered debris include frequency of cleanup crews and mowing practices along roadsides. Almost all roadsides in our study had mowed areas adjacent to paved roads. We frequently noticed broken bottles in these areas and attributed them to mowing; these bottles were not counted in our survey.
Characteristics of littered debris fatal to small vertebrates in central Nebraska generally matched other studies. Glass bottles accounted for the large majority (92\%) of vertebrate mortalities (Table 1), as demonstrated in other studies that recorded such data (Benedict and Billeter 2004, Hamed and Laughlin 2015). In contrast, Brannon et al. (2010) reported an abundance of skeletal remain in both glass and plastic bottles. We documented not a single vertebrate mortality in aluminum cans, similar to Brannon et al. (2010). Other studies have not reported or examined potential mortalities in littered cans (Benedict and Billeter 2004, Brannon and Bargelt 2013). A single study in Tennessee reported that $1 \%$ of aluminum cans contained small shrew species (Sorex; Hamed and Laughlin 2015).

Bottles with openings higher than their base contained more vertebrates than those in other positions. Other studies also have reported that bottles pointed upward are associated with more mortalities (Benedict and Billeter 2004, Brannon et al. 2010, Brannon and Bargelt 2013, Hamed and Laughlin 2015). We discovered more vertebrates trapped in brown glass bottles than other colors (Table 1); however, we did not note the colors of bottles without vertebrates in this study. Other studies have reported that vertebrate mortalities match the relative frequency of differently colored bottles in the environment (Benedict and Billeter 2004, Hamed and Laughlin 2015). Two prior studies demonstrated that brown-colored bottles were the most frequent in environments in the eastern United States (Benedict and Billeter 2004, Hamed and Laughlin 2015). Lastly, we documented most vertebrates in smaller, $360 \mathrm{ml}(12 \mathrm{oz})$, bottles, again likely reflecting the abundance of smaller containers in the environment (Table 1).

In the Great Plains, roadside right-of-ways represent some of the last grasslands remaining in these agriculturally dominated landscapes, providing habitat for an abundance and diversity of small mammals (Kirsch 1997, Spanel and Geluso 2018). Living along roadways is inherently dangerous as organisms are killed crossing roads, including small mammals (McClure 1951, Oxley et al. 1974). Littered debris adds to the dangers for small organisms in such habitats. Our study further demonstrates that not only do physically small species fall victim to littered bottles but also young individuals of larger species (Benedict and Billeter 2004). Without picking up or breaking bottles, these debris items can accumulate in the environment and continue to kill animals. Reduction and removal of littered debris along roadsides not only is 
aesthetically pleasing, but it can reduce mortality of small mammals and other small animals.

Acknowledgments We thank T. Zikmund for helping to find sites with bottles in Harlan County and Z. Graham for assistance with locations in Cherry County. We thank J. Falconer, D. Holcomb, and J. Kuebler for administrative assistance throughout this project. We thank R. Benedict and an anonymous reviewer for comments that improved this manuscript. This project was funded by the Summer Student Research Program (SSRP) for undergraduate students at the University of Nebraska at Kearney.

\section{Literature Cited}

Benedict RA, and Billeter MC. (2004) Discarded bottles as a cause of mortality in small vertebrates. Southeastern Naturalist 3: 371-377.

Berman J, McCay T, and Scull P. (2007) Spatial analysis of species richness of shrews (Soricomorpha: Soricidae) in North America north of Mexico. Acta Theriologica 52: 151-158.

Brannon MP, and Bargelt LB. (2013) Discarded bottles as a mortality threat to shrews and other small mammals in the southern Appalachian Mountains. Journal of the North Carolina Academy of Science 129: 126-129.

Brannon MP, Burt MA, Bost DM, and Caswell MC. (2010) Discarded bottles as a source of shrew species distributional data along an elevational gradient in the southern Appalachians. Southeastern Naturalist 9: 781-794.

Carraway LN. (1995) A key to recent Soricidae of the western United States and Canada based primarily on dentaries. Occasional Papers of the Natural History Museum, University of Kansas, Lawrence 175: 1-49.

Castilla AM, and Bauwens D. (1991) Observations on the natural history, present status, and conservation of the insular lizard Podarcis hispanica atrata on the Columbretes Archipelago, Spain. Biological Conservation 58: 69-84.

Clegg TM. (1966) The abundance of shrews as indicated by trapping and remains in discarded bottles. Naturalist (Hull) 899: 122.

Debernardi P, Patriarca E, Perrone A, Cantini M, and Chiarenzi B. (1997) Small mammals found in discarded bottles in alpine and pre-alpine areas of NW-Italy. Hystrix 9: 51-55.

Dreier CA, Buerer RA, and Geluso K. (2015a) Sceloporus consobrinus (Prairie Lizard): mortality. Herpetological Review 46: 94-95.

Dreier CA, Geluso K, Frisch JD, Adams BN, Lingenfelter AR, Bridger AE, Freeman PW, Lemen CA, White JA, Andersen BR, Otto HW, and Schmidt CJ. (2015b) Mammalian records from southwestern Kansas and northwestern Oklahoma, including the first record of Crawford's desert shrew (Notiosorex crawfordi) from Kansas. Occasional Papers, Museum of Texas Tech University 333: 1-11.

Forman RTT, and Alexander LE. (1998) Roads and their major ecological effects. Annual Review of Ecology and Systematics 29: 207-231.

Gall SC, and Thompson RC. (2015) The impact of debris on marine life. Marine Pollution Bulletin 92: 170-179.

Genoways HH, Hoffman JD, Freeman PW, Geluso K, Benedict RA, and Huebschman JJ. (2008) Mammals of Nebraska: checklist, key, and bibliography. Bulletin of the University of Nebraska State Museum 23: 1-92.

Gerard AS, and Feldhamer GA. (1990) A comparison of two survey methods for shrews: pitfalls and discarded bottles. American Midland Naturalist 124: 191-194.

Gibbs JP, and Shriver WG. (2002) Estimating the effects of road mortality on turtle populations. Conservation Biology 16: $1647-1652$.

Glista DJ, DeVault TL, and DeWoody JA. (2009) A review of mitigation measures for reducing wildlife mortality on roadways. Landscape and Urban Planning 91: 1-7.

Hafner DJ, Yensen E, and Kirkland GL Jr. (1998) North American rodents: status, survey and conservation action plan. IUCN/SSC Rodent Specialist Group. IUCN, Gland, Switzerland, and Cambridge, UK. 171 pp.

Hamed MK, and Laughlin TF. 2015. Small-mammal mortality caused by discarded bottles and cans along a US Forest Service Road in the Cherokee National Forest. Southeastern Naturalist 14: 506-516.

Jones JK, Jr. (1964) Distribution and taxonomy of mammals of Nebraska. University of Kansas Publications, Museum of Natural History 16: 1-356.

Keller I, and Largiadèr CR. (2003) Recent habitat fragmentation caused by major roads leads to reduction of gene flow and loss of genetic variability in ground beetles. Proceedings of the Royal Society of London B 270: 417-423.

Kirsch EM. (1997) Small mammal community composition in cornfields, roadside ditches, and prairies in eastern Nebraska. Natural Areas Journal 17: 204-211.

Kolenda K, Przybył M, Piłacińska B, and Rychlik L. (2018) Survey of discarded bottles as an effective method in detection of small mammal diversity. Polish Journal of Ecology 66: 57-63.

Krutilla JV. (1967) Some environmental effects of economic development. Daedalus 96: 1058-1070.

Matlack RS, Kaufman DW, Kaufman GA, and McMillan BR. (2002) Long-term variation in abundance of Elliot's Shorttailed Shrew (Blarina hylophaga) in tallgrass prairie. Journal of Mammalogy 83: 280-289.

McClure HE. (1951) An analysis of animal victims on Nebraska's highways. Journal of Wildlife Management 9: 295-319.

Morris PA, and Harper JF. (1965) The occurrence of small mammals in discarded bottles. Proceedings of the Zoological Society of London 145: 148-153. 
Oxley DJ, Fenton MB, and Carmody GR. (1974) The effects of roads on populations of small mammals. Journal of Applied Ecology 11: 51-59.

Pagels JF, and French TW. (1987) Discarded bottles as a source of small mammal distribution data. American Midland Naturalist 118: 217-219.

Perkl R, Norman LM, Mitchell D, Feller M, Smith G, and Wilson NR. (2018) Urban growth and landscape connectivity threats assessment at Saguaro National Park, Arizona, USA. Journal of Land Use Science 13: 102-117.

Rochman CM, Browne MA, Underwood AJ, van Franeker JA, Thompson RC, and Amaral-Zettler LA. (2016) The ecological impacts of marine debris: unraveling the demonstration evidence from what is perceived. Ecology 97: 302-312.

Samson F, and Knopf F. (1994) Prairie conservation in North America. BioScience 44: 418-421.
Schneider R, Fritz M, Jorgensen J, Schainost S, Simpson R, Steinauer G, and Rothe-Groleau C. (2018). Revision of the Tier 1 and 2 lists of Species of Greatest Conservation Need: a supplement to the Nebraska Natural Legacy Project State Wildlife Action Plan. (Lincoln, Nebraska: The Nebraska Game and Parks Commission).

Spanel TJ, and Geluso K. (2018) Small mammals in cornfields and associated peripheral habitats in central Nebraska. Transactions of the Nebraska Academy of Sciences 38: 30-35.

Taylor-Brown A, Booth R, Gillett A, Mealy E, Ogbourne SM, Polkinghorne A, and Conroy GC. (2019) The impact of human activities on Australian wildlife. PLOS ONE 14(1): e0206958.

Thompson CW, Choate JR, Genoways HH, and Finck EJ. (2011) Blarina hylophaga (Sorciomorpha: Soricidae).

Mammalian Species 43: 94-103. 